\title{
Pulse and frequency responses of broadband low frequency ultrasonic transducers
}

\author{
A. Vladišauskas, L. Mažeika, R. Šliteris, R. Raišutis, A. Jankauskas
}

Ultrasound Institute, Kaunas University of Technology, Studentu 50, LT-51368 Kaunas, Lithuania,

Phone: +370 37 351162, Fax. +370 37451489

\begin{abstract}
In this article investigation of low frequency broadband contact type ultrasonic transducers is described. A few types of the driving pulses were used in the frequency range from $50 \mathrm{kHz}$ up to $350 \mathrm{kHz}$. Numerical simulations and experimental investigations were performed. The main dependencies of the frequency responses are in a good coincidence for both cases. The spectrum magnitude of the three periods of the driving pulse has the bandwidth of lobes 3 times narrower than the in the case of a single driving pulse.

The ultrasonic transducers with and without the replaceable protectors were investigated. It was obtained that the first period of the pulse response possesses high steepness suitable to be used for time of flight measurements. The second and the third periods of the signal are wider due to compression type vibrations of the piezoelement. The convex replaceable protector gives additional losses of ultrasonic signal and changes the frequency response giving the extra minimum values at some frequencies.
\end{abstract}

Keywords: frequency response, replaceable protector, pulse response, contact type scanning, broadband transducer.

\section{Introduction}

Low frequency transducers are widely applied in various fields of the ultrasonic investigations such as nondestructive testing, characterisation of materials, measurement of acoustic emission, flow measurements and etc.. Therefore, they can be used for different ultrasonic applications, such as air-coupled, immersion and contact, also a mixing of these methods for obtaining of an optimum amount of the information. The air-coupled investigations are limited due to essential losses of the signal [1-3]. In order to decrease the losses of air-coupled transducers, the active aperture of the transducer could be increased, but simultaneously the achievable spatial resolution becomes lower. Another way to increase the signal to noise ratio is to use the immersion and the contact method in such a way that the acoustic impedance of the coupling medium will be close to the acoustic impedance of the investigated object [4]. It can be achieved by fixing the transmitting transducer on the edge of the object under investigation and scanning of the receiving transducer over it. In another immersion method the transmitting transducer was permanently fixed by epoxy glue on the surface of the aluminium plate [5]. The receiver was placed at the distance of $10 \mathrm{~mm}$ over the plate and scanned along two perpendicular directions.

Many ultrasonic transducers are used for low frequency investigations. They can be divided into three groups:

- air-coupled transducers;

- immersion transducers;

- contact transducers.

This is due to the fact that the acoustic impedance of the environment considerably differs from the acoustic impedance of the matching layer of the transducer. The aircoupled transducers usually consist of a few matching layers. The last matching layer possesses very low acoustic impedance for good matching with the surrounding medium (air). Therefore, these transducers are not used for mechanical contact type scanning.

The immersion transducers can be used in the mechanical scanning device.

The investigation of the carbon fiber reinforced plastics rods using contact and immersion techniques was performed [3]. The ultrasonic transmitting transducer with a small diameter ( $4 \mathrm{~mm}$ ) was mounted on the edge of the rod and the receiving ultrasonic transducer with the same diameter has been scanned over the surface of the sample in order to register leaky waves.

The low frequency, broadband transducers with the additional protectors are needed to ensure a long-term scanning and to increase the resistance of the contacting part of the transducer against abrasion [6-8]. It can be achieved if the characteristics of the low frequency broadband transducers within the frequency bandwidth are known.

Usually, such characteristics are complicated due to shape and duration of the driving pulse, frequency response of the transducer, effect of spatial filtering due to finite size of the transducer surface and the complex transfer function of the object under investigation.

The aim of this work is to investigate the pulse and frequency responses of the broadband contact type ultrasonic transducers and to determine the distortions due to modification of their construction.

\section{Investigation of the influence of the driving pulses}

At the first step of investigations, it is necessary to determine the possibilities to excite the broadband signals by the appropriate driving pulses. For that the simulations and the experimental investigation were performed.

The two cases of driving signals having the unipolar rectangular shape were simulated: the single positive pulse and the positive burst of 3 periods. The pulse was simulated using equation: 


$$
\begin{gathered}
u(t)= \begin{cases}1, & t<\frac{T}{2}, \quad T=\frac{1}{f}, \\
0, & \frac{T}{2}<t<T,\end{cases} \\
u(t)=\sum_{n-1}^{N} u(t+n \cdot T),
\end{gathered}
$$

where $T$ is the period of the signal $u(t), t$ is the time, $f$ is the frequency of the signal, $N$ is the number of periods in burst. Waveforms of the normalized driving pulses are presented in Fig.1 $a$ and $b$.

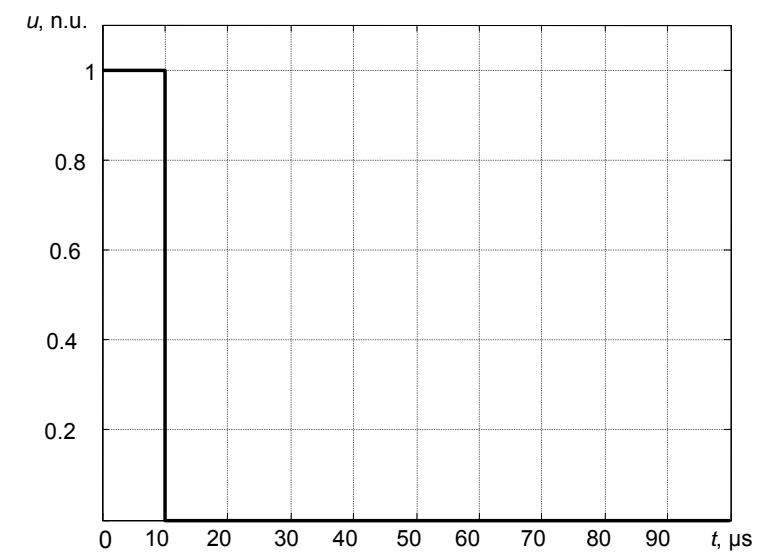

a

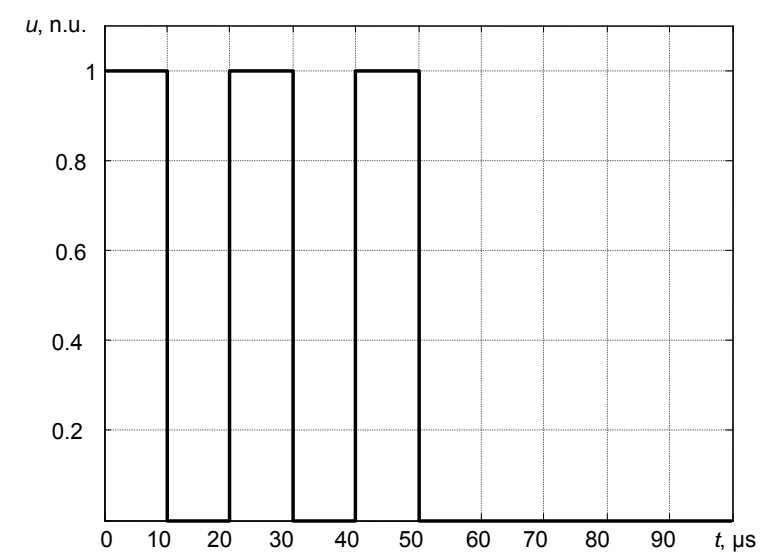

b

Fig. 1. The driving pulses: $\mathbf{a}$ - single positive pulse; $\mathbf{b}$ - positive burst of 3 periods

The ultrasonic measurement system Ultralab (Ultrasound institute, Kaunas University of technology) was used for investigation of the transducers and formation of the driving pulses having amplitudes of $20 \mathrm{~V}$. The duration of the excitation pulse (the half of the period) was changed from $10 \mu \mathrm{s}$ (for $50 \mathrm{kHz}$ ) up to $1.43 \mu \mathrm{s}$ (for $350 \mathrm{kHz}$ ). The amplitudes of the driving pulses were registered experimentally, also. For registration the digital oscilloscope Agilent Infiniium 54830B DSO, connected in parallel to the transmitting transducer, was used. The sampling frequency was $100 \mathrm{MHz}$. Waveforms of the acquired signals in the case of a single pulse and the burst of 3 periods corresponds very well to simulated presented in Fig. 1a and b.
The simulated and the experimental spectra magnitudes were obtained at frequencies from $50 \mathrm{kHz}$ up to $350 \mathrm{kHz}$. The results of the investigation are shown in Fig.2, 3 and 4 for three cases of the single driving pulse: $50 \mathrm{kHz}$ (duration of $10 \mu \mathrm{s}$ ), $150 \mathrm{kHz}$ (duration of $3.33 \mu \mathrm{s}$ ) and $350 \mathrm{kHz}$ (duration of $1.43 \mu \mathrm{s}$ ).

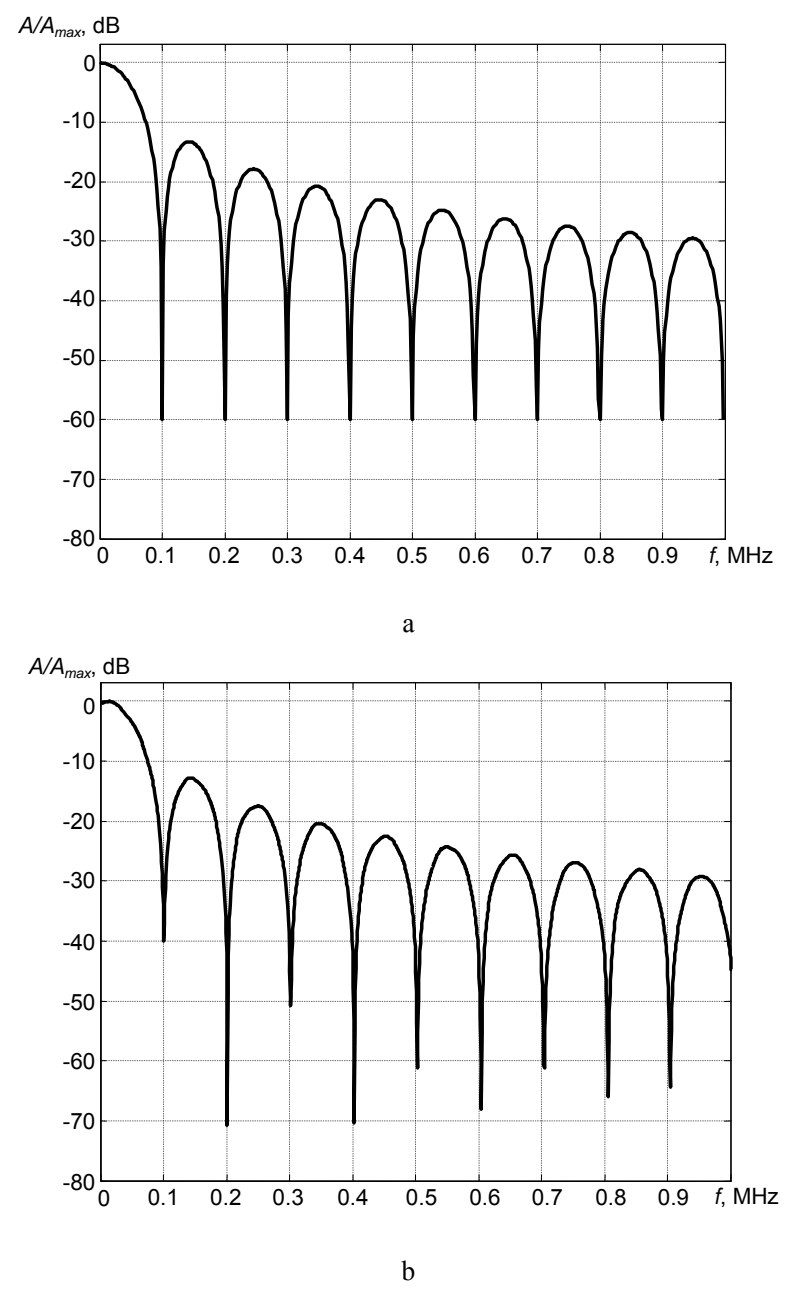

Fig. 2. The simulated and the experimental spectrum magnitudes of the single driving pulse of $50 \mathrm{kHz}$ (duration of $10 \mu \mathrm{s}$ ): a simulation, b - experimental

The simulated spectrum magnitude has the maximum values at the odd harmonics and the uniform minimum values $(-60 \mathrm{~dB})$ on the even harmonics. The maximum values of the experimental spectrum magnitude are very similar to the simulated one, but the minimum values are different, especially at the low frequencies. It is necessary to note that in the simulation the losses were not evaluated. In the experimental investigation the generator output of the measurement system was loaded by the complex impedance of the broadband low frequency transducer [68]. In both cases the spectrum magnitudes consist of many lobes distributed repetitively at each $100 \mathrm{kHz}$. The bandwidth of each lobes at the $-6 \mathrm{~dB}$ is $f=74 \mathrm{kHz}$.

The simulated and experimental spectrum magnitudes of the single driving pulse of $150 \mathrm{kHz}$ (duration of $3.33 \mu \mathrm{s}$ ) are shown in Fig. 3a and $b$. The number of minimum values in the both spectrum magnitudes decreases by three times and the bandwidths of lobes increase up to $210 \mathrm{kHz}$. 
$A / A_{\max }, \mathrm{dB}$

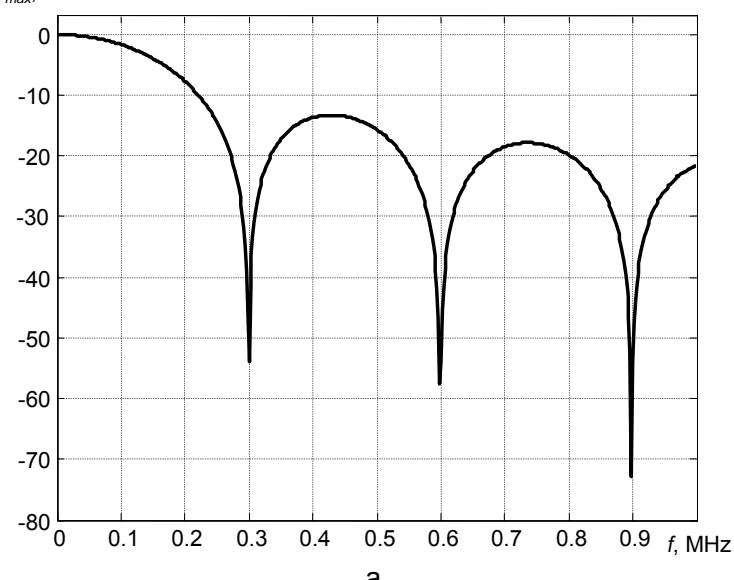

$A / A_{\max }, \mathrm{dB}$

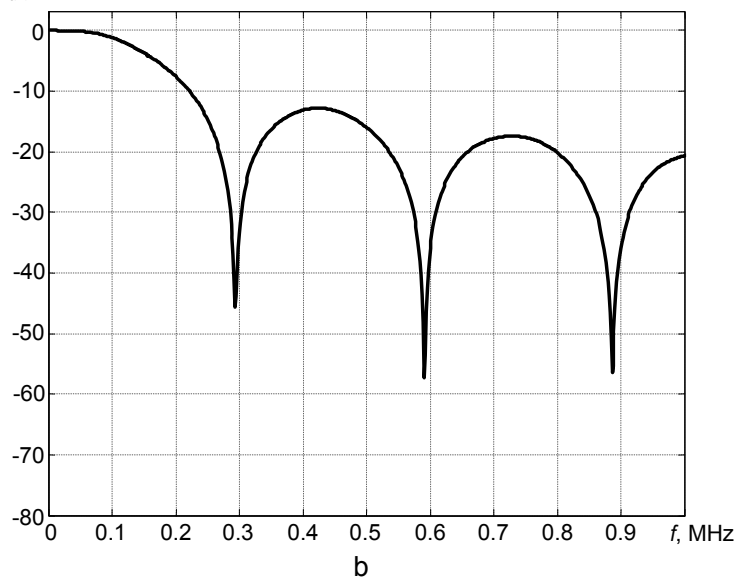

Fig. 3. The simulated and the experimental spectrum magnitude of the single driving pulse of $150 \mathrm{kHz}$ (duration of $3.33 \mu \mathrm{s}$ ): a- simulation, b- experimental

The simulated and the experimental spectrum magnitudes of the single driving pulse of $350 \mathrm{kHz}$ are shown in Fig.4a and b. In this case there is only one minimum at the frequency of $700 \mathrm{kHz}$. The bandwidth of the main lobe is $400 \mathrm{kHz}$ at $-6 \mathrm{~dB}$.

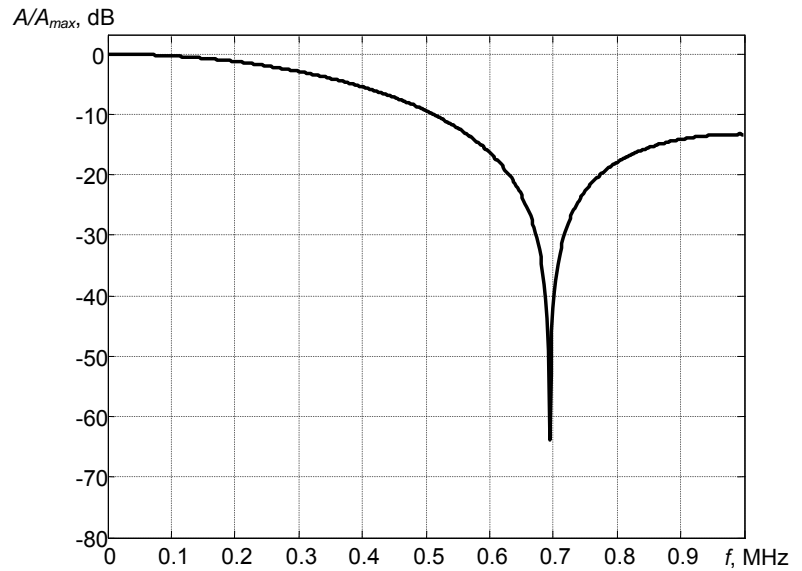

Thus decreasing the duration of driving pulse causes more broadband lobes of the spectrum magnitude. It improves the ultrasonic visualization and the possibilities of ultrasonic investigation within the bandwidth.

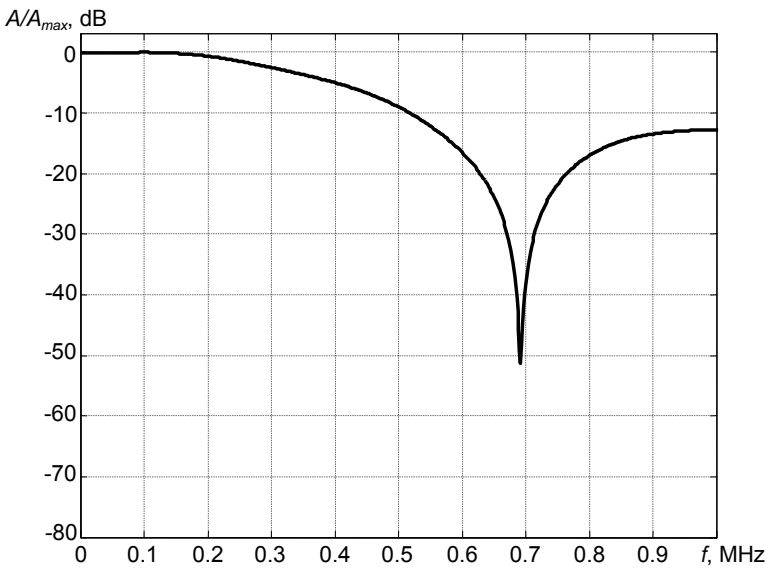

b

Fig. 4. The simulated and the experimental spectrum magnitude of the single driving pulse of $350 \mathrm{kHz}$ : a- simulation, b - experimental

$A / A_{\max }, \mathrm{dB}$

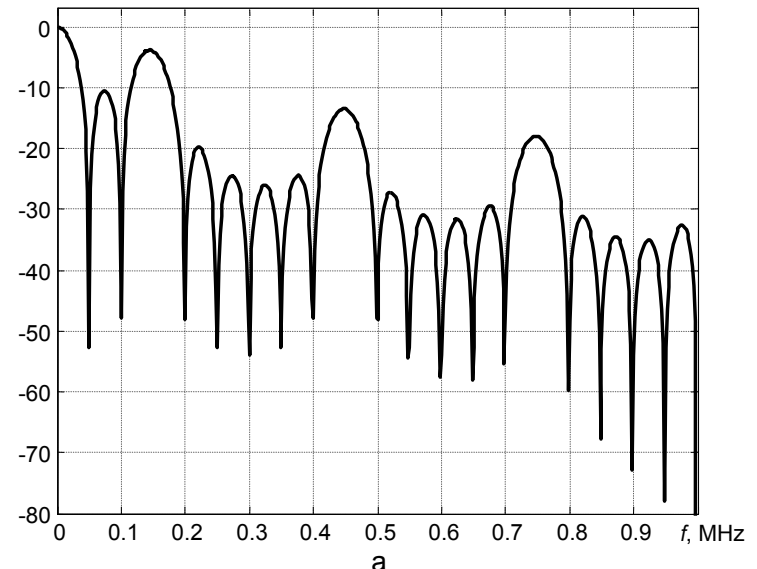

$A / A_{\max }, \mathrm{dB}$

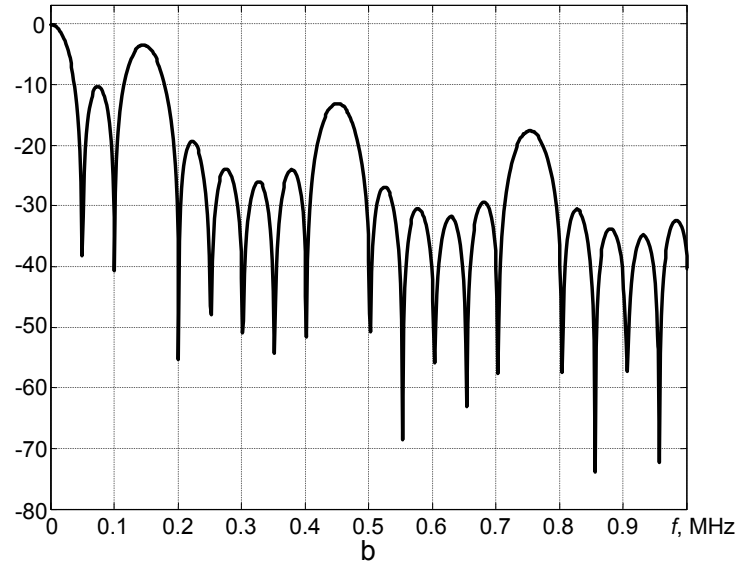

Fig. 5. The simulated and the experimental spectrum magnitudes of the three periods driving burst of $150 \mathrm{kHz}$ : a - simulation, b - experimental 
However, the shorter driving pulse causes the lower amplitude of the ultrasonic signal needed for the investigation process.

In order to increase the signal to noise ratio of the ultrasonic signal, the transmitter can be driven by a burst of 3 periods (Fig. 1b).

The simulated and the experimental spectrum magnitudes from $50 \mathrm{kHz}$ up to $350 \mathrm{kHz}$ were estimated and the driving amplitudes were the same as during investigation of the single driving pulse.

The spectrum magnitudes using three periods of the driving pulse of $150 \mathrm{kHz}$ are shown in Fig. 5a and b. The bandwidth of lobes of the theoretical and experimental spectrum magnitudes is $66 \mathrm{kHz}$. It means that the bandwidth is 3 times narrower comparing with the single pulse.

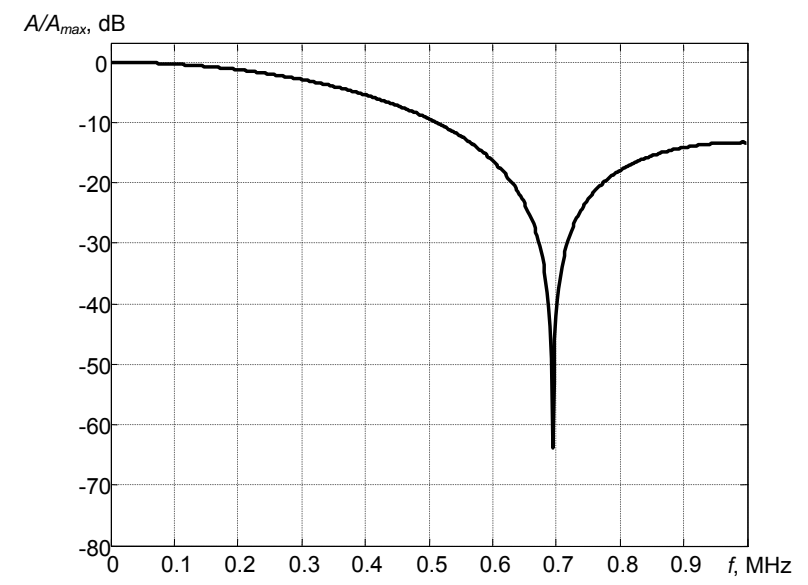

a

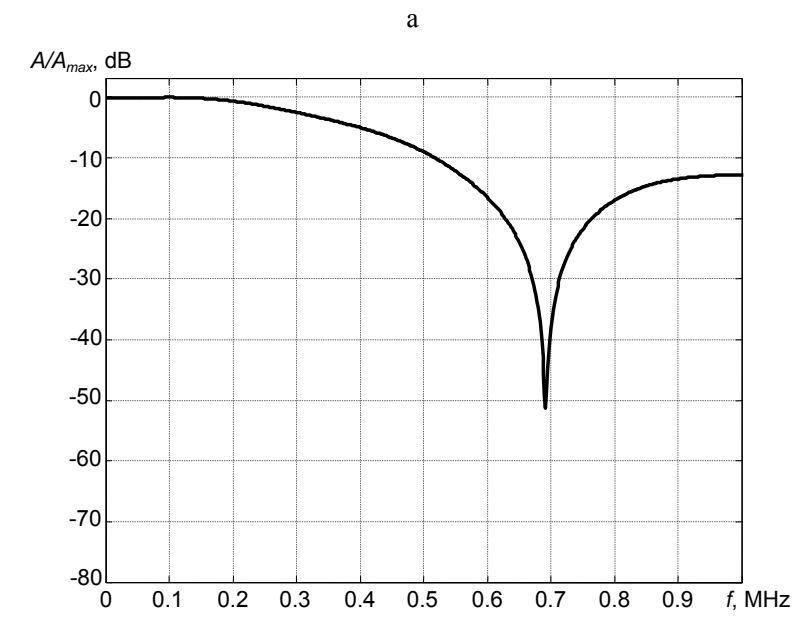

b

Fig. 6. The simulated and the experimental spectrum magnitudes of the three periods driving burst of $350 \mathrm{kHz}$ : a - simulation, b experimental

The frequency responses using three periods of the driving pulse of $350 \mathrm{kHz}$ are shown in Fig. 6a and b. In this case the bandwidth of lobes is also 3 times narrower than in the case of the single pulse. In this way the increase of the signal amplitude is obtained due to decrease of the broadband effect of the driving pulse.

\section{Frequency and pulse responses of the contact type} transducers without replaceable protector

The scanning of the object by using the ultrasonic waves enables to get more useful information if the broadband ultrasonic signals are used. It increase possibilities to excite a few types of ultrasonic waves in the investigation object simultaneously, to shorten investigation time, to increase measurement accuracy of the materials parameters and dimensions of defects. It can be achieved if the possibilities and characteristics of the broadband ultrasonic transducers which are exited by the broadband pulses are known. The very short excitation pulse (single pulse) of $200 \mathrm{~V}$ and $0.5 \mu$ s was used in order to determine the frequency response of the broadband transducer [6, 7]. The excitation of very short pulse is not efficient in long range investigations (ultrasonic guided wave technique) of the materials with a high attenuation of ultrasonic waves.

The experimental investigations of the pulse and frequency responses were carried out without and with the additional protector (Fig. 7). The acoustic contact between the transmitter and the receiver was obtained by a coupling liquid (glycerol). In this case the excitation by the three periods burst [6-8] with the amplitude of $20 \mathrm{~V}$ was used.
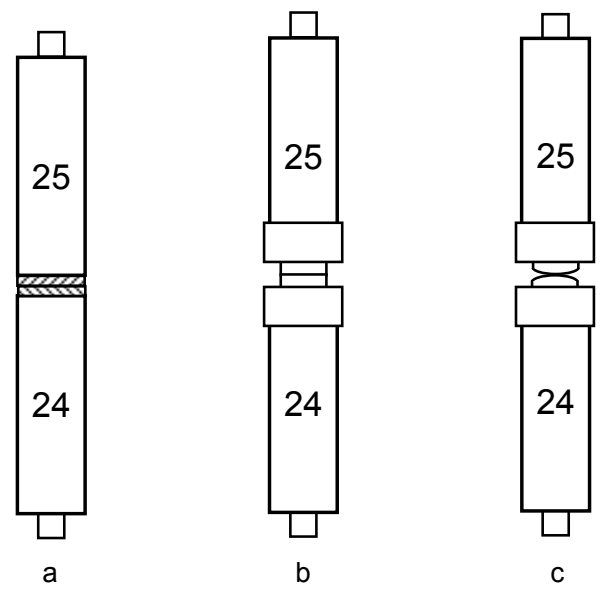

Fig. 7. The measurement schemes: a - without additional protector, b - with planar additional protector, $\mathrm{c}$ - with convex protector

The different driving pulses were used: the single pulse having the amplitude of $20 \mathrm{~V}$ (Fig. 1a) and three periods of the rectangular pulse having the same amplitude (Fig. 1b). The duration of the excitation pulse was changed from $10 \mu \mathrm{s}$ (for $50 \mathrm{kHz}$ ) up to $1.25 \mu \mathrm{s}$ (for $400 \mathrm{kHz}$ ).

The experimental investigations were carried out without a replaceable protector for determination of the reference pulse and frequency responses of the low frequency broadband contact type transducers. Two transducers (the transmitter and the receiver), operating in a direct contact (face to face) through the coupling liquid were used. The pulse and frequency responses of the exciting pulse having duration of $10 \mu$ s and amplitude of $20 \mathrm{~V}$ are shown in Fig. 8 and 9. 


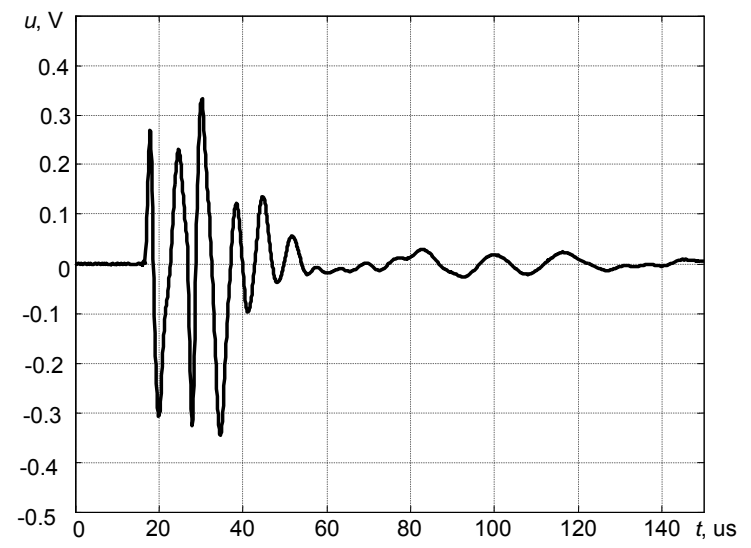

Fig. 8. The pulse response of the low frequency broadband transducer excited by a single pulse having duration $10 \mu \mathrm{s}$

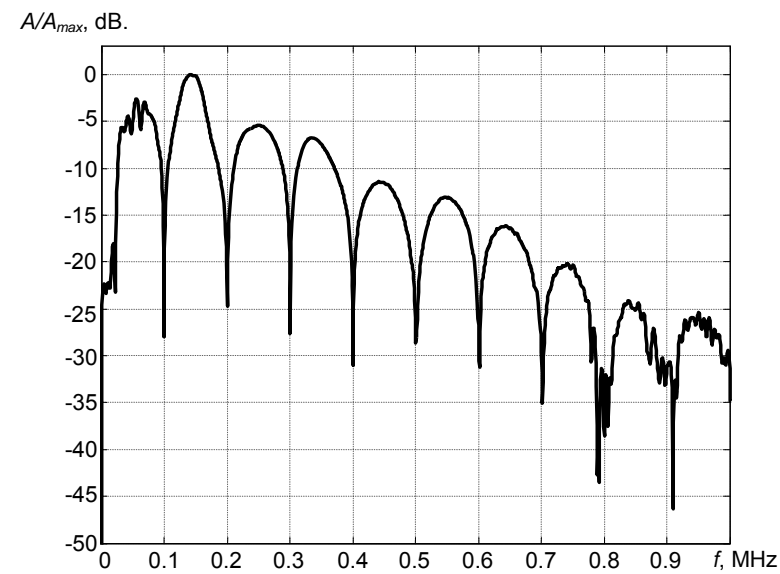

Fig. 9. The frequency response of the low frequency broadband transducer excited by a single pulse having duration $10 \mu \mathrm{s}$

The first period of the pulse response is suitable to be used for the time of flight measurements.

The second and the third periods of the signal are elongated typically due to the volume mode vibration.

The frequency response of the low frequency broadband transducer is shown in Fig. 9. The bandwidth of lobes and their amplitudes are very similar to the previous case of the driving pulses, except the beginning of frequency response $(0-20) \mathrm{kHz}$. In this part the first maximum is located at $50 \mathrm{kHz}$.

At higher frequencies $(150 \mathrm{kHz}$ and $300 \mathrm{kHz})$ the pulse responses become shorter (Fig.10 and Fig. 11). The first period of the pulse response changes a little and possesses a higher steepness. This enables to get a high accuracy of time of flight measurements of arriving ultrasonic signals.

The frequency responses according to the pulse responses of $150 \mathrm{kHz}$ and $300 \mathrm{kHz}$ are shown in Fig. 12 and Fig.13. The minimum values of the frequency response of $150 \mathrm{kHz}$ completely coincide with the modeling results presented in Fig. $3 \mathrm{~b}$. However, the minimum values of amplitudes are different. In the experimental investigation the minimum value of the amplitude at $300 \mathrm{kHz}$ is $-25 \mathrm{~dB}$, though in the modeling this value is $-45 \mathrm{~dB}$. In such a way at the higher frequencies the minimum values become smaller. It can be seen in Fig.13, that the minimum amplitude at $600 \mathrm{kHz}$ is $-30 \mathrm{~dB}$.

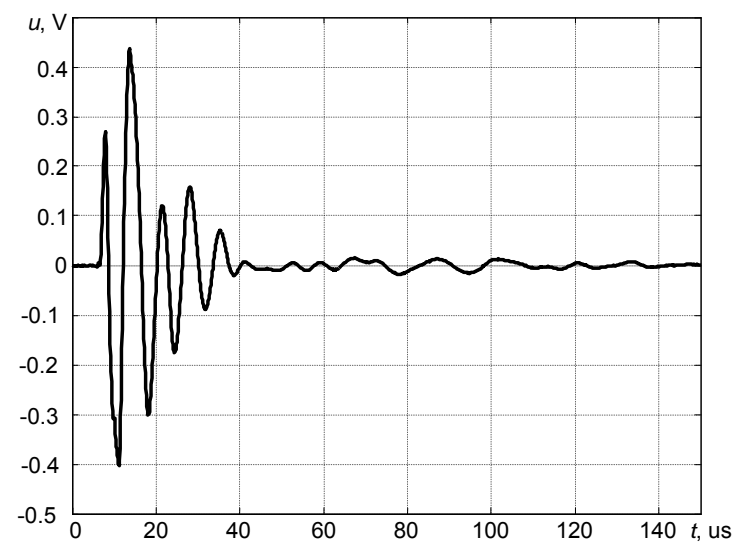

Fig. 10. The pulse response (single pulse of $150 \mathrm{kHz}$, duration $3.33 \mu \mathrm{s}$ )

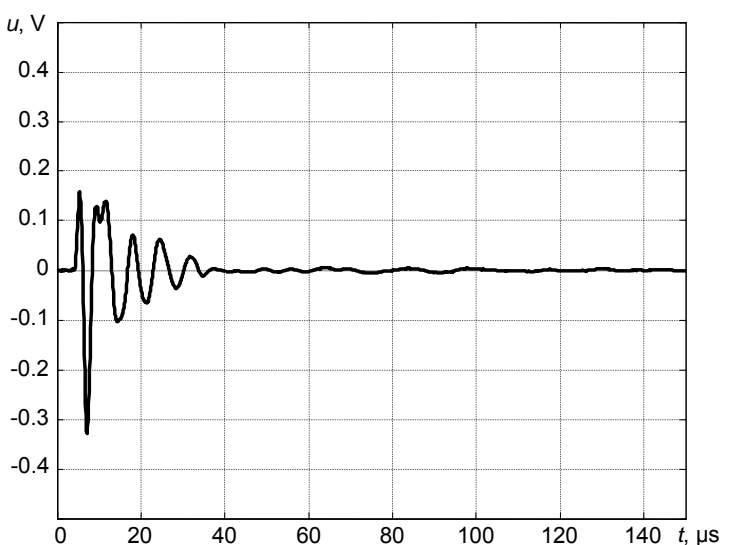

Fig. 11. The pulse response (single pulse of $300 \mathrm{kHz}$, duration $1.67 \mu \mathrm{s}$ )

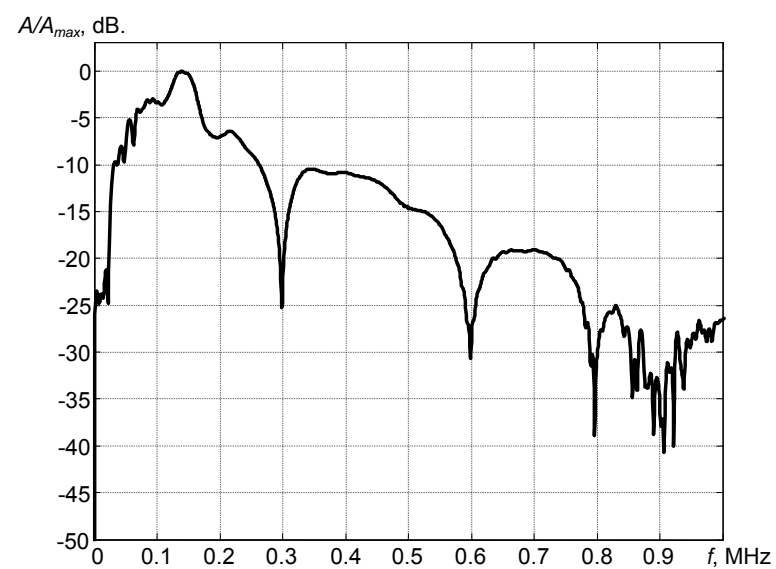

Fig. 12. The frequency response (single pulse of $150 \mathrm{kHz}$, duration $3.33 \mu \mathrm{s})$ 


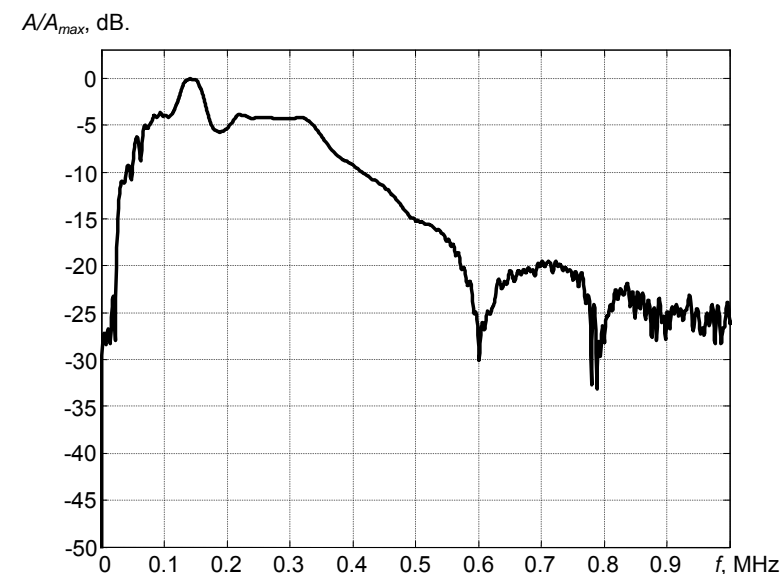

Fig. 13. The frequency response (single pulse of $300 \mathbf{~ k H z}$, duration of $1.67 \mu \mathrm{s})$

\section{Frequency and pulse responses of the contact transducers with replaceable protector}

The application of low frequency broadband transducers which are used in contact scanning systems require transducers without significant change of the characteristics or to use the changeable part of transducer which can provide identical characteristics. It can be achieved using the replaceable protector, furthermore, this protector can be used many times. Also, the replaceable protector enable control the operation characteristics of transducer without change of the main construction of the transducer. Two types of the replaceable protector were used during investigation of the pulse and frequency responses of the low frequency broadband transducer (Fig. $7 \mathrm{~b}$ and $\mathrm{c})$ : the planar and the convex. The planar replaceable protector with the diameter of $5 \mathrm{~mm}$ and thickness of $3 \mathrm{~mm}$ was used for each transducer in a through transmission mode. The pulse response of the low frequency broadband transducer with the planar replaceable protector is shown in Fig.14. The exciting pulse was the single of the $50 \mathrm{kHz}$ frequency (duration $10 \mu \mathrm{s})$ pulse. The losses of the ultrasonic signal of the two planar protectors are higher by $10 \mathrm{~dB}$ (due to attenuation in the protector) as compared with the results obtained without the additional protector.

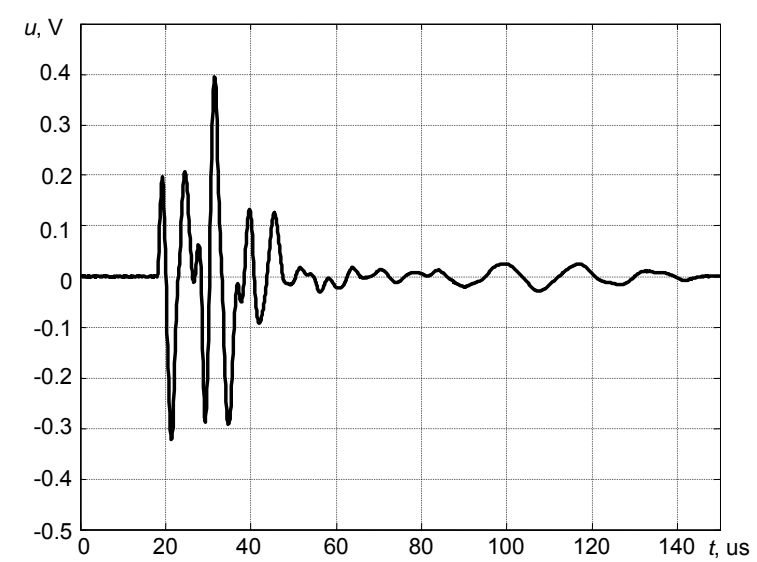

Fig. 14. The pulse response of the planar replaceable protector (single pulse of $50 \mathrm{kHz}$, duration of $10 \mu \mathrm{s}$ )
The pulse response becomes more complicated in comparison with the pulse response without the replaceable protector. However, the first period remains the same as in the case without the replaceable protector.

The frequency response of the transducer with the replaceable protector (Fig. 15) is very similar to the frequency response without the replaceable protector (Fig. 9).

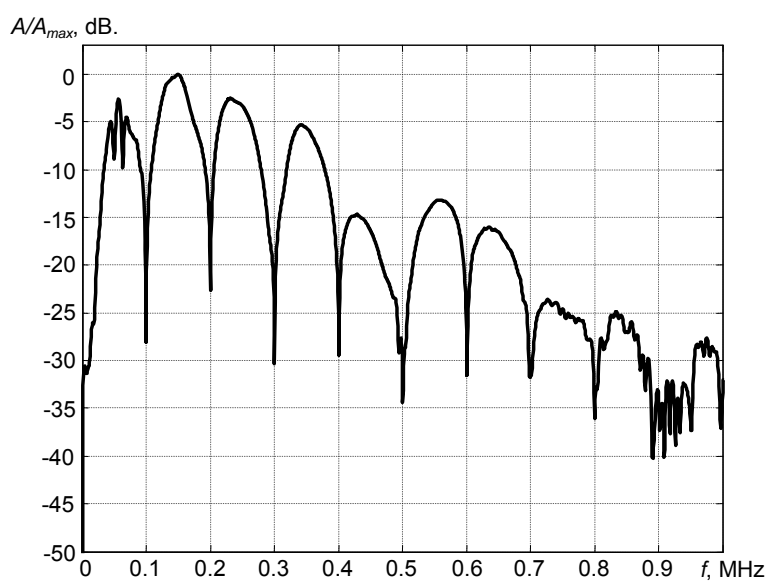

Fig. 15. The frequency response of the planar replaceable protector (single pulse of $50 \mathrm{kHz}$, duration of $10 \mu \mathrm{s}$ )

It means that at the $50 \mathrm{kHz}$ the planar replaceable protector doesn't affects the characteristics of the transducer. There is only a small difference at the frequency $500 \mathrm{kHz}$.

Very similar responses were obtained at a higher frequency (Fig. 17). This planar replaceable protector is very useful for the long-term ultrasonic scanning systems. The thickness of the replaceable protector can be wearied away due to abrasion without significant change of the frequency response. The pulse response indicates reduction of the signal amplitude but the shape of the first period is not significantly affected.

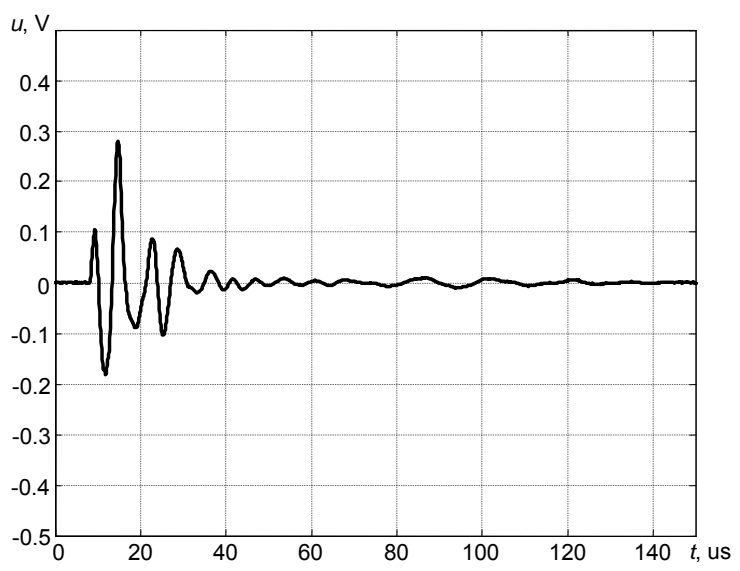

Fig. 16. The pulse response of the planar replaceable protector (single pulse of $150 \mathrm{kHz}$, duration of $3.33 \mu \mathrm{s}$ ) 


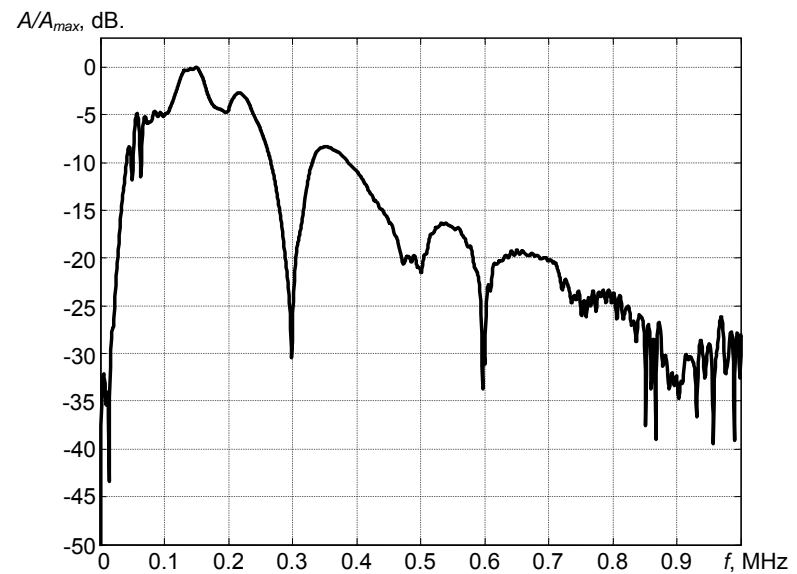

Fig. 17. The frequency response of the planar replaceable protector (single pulse of $150 \mathrm{kHz}$, duration of $3.33 \mu \mathrm{s}$ )

The convex replaceable protector has the thickness of $3 \mathrm{~mm}$, the diameter of $5 \mathrm{~mm}$ in the side to be attached to the ultrasonic transducer and the diameter of the contact area was $0.1 \mathrm{~mm}$. The pulse response of $50 \mathrm{kHz}$ (Fig. 18) has a different shape comparing to the case of planar protector. The first period of the pulse possesses a low amplitude and the maximum of the amplitude is achieved only after 3 periods of vibration. The losses of the convex replaceable protector are close to $-15 \mathrm{~dB}$ and depend on the area of contact.

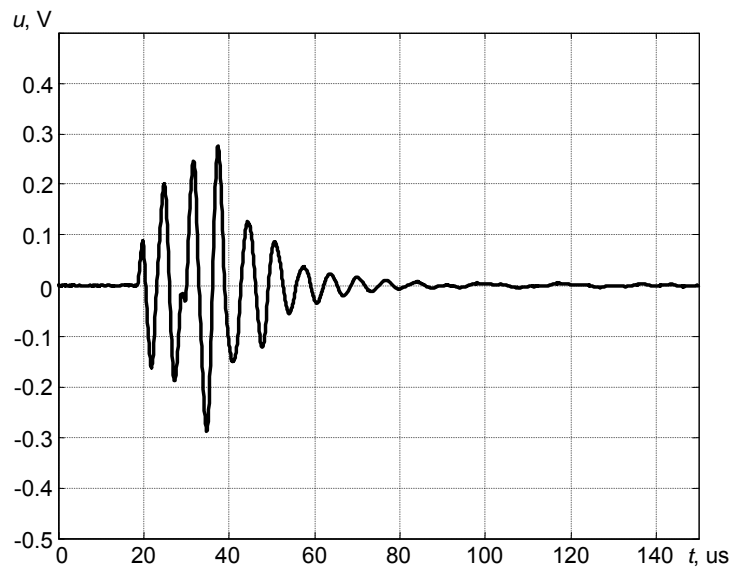

Fig. 18. The pulse response of the convex replaceable protector (single pulse of $50 \mathrm{kHz}$, duration of $10 \mu \mathrm{s}$ )

The frequency response of the $50 \mathrm{kHz}$ has a few extra minimum values, which are determined by the shape and the size of the convex protector (Fig.19).

The pulse response of the single pulse of $200 \mathrm{kHz}$ (duration of $2.5 \mu \mathrm{s}$ ) is presented in Fig. 20.

The use of the convex replaceable protector restricts the bandwidth of transducers, even in the case of a very short excitation pulse, for example $0.5 \mu \mathrm{s}$. Two extra minimum values are shown in Fig. 21, where the amplitudes of the frequency response at the frequencies of $300 \mathrm{kHz}$ and $500 \mathrm{kHz}$ are decrease by $-(10-12) \mathrm{dB}$. It can give the effect of measurement information losses in further investigations.

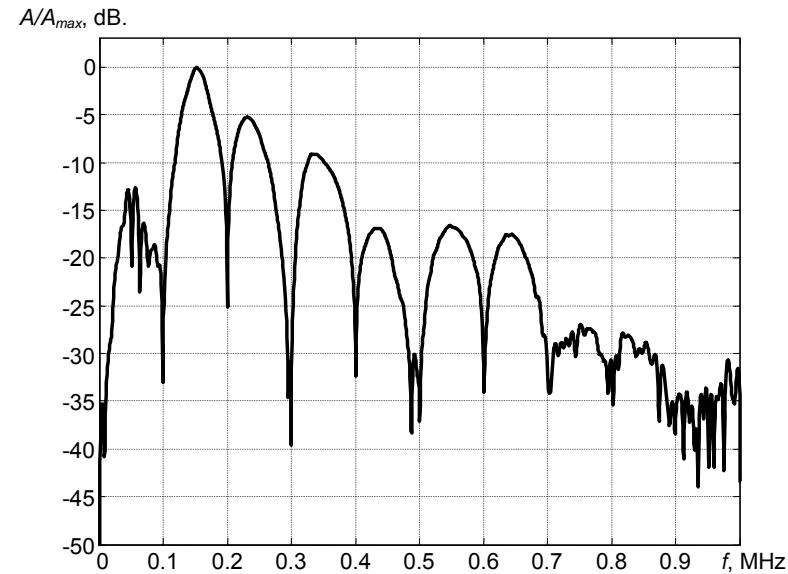

Fig. 19. The frequency response of the convex replaceable protector (single pulse of $50 \mathrm{kHz}$, duration of $10 \mu \mathrm{s}$ )

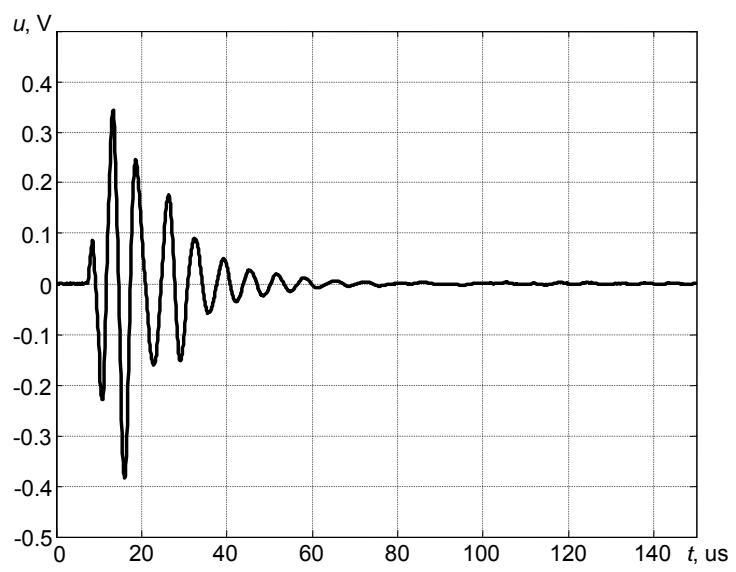

Fig. 20. The pulse response of the convex replaceable protector (single pulse of $200 \mathrm{kHz}$, duration of $2.5 \mu \mathrm{s}$ )

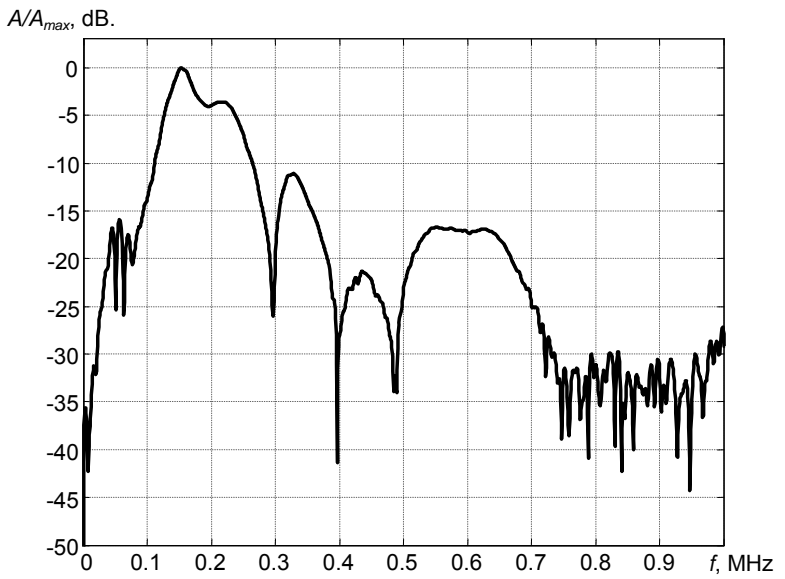

Fig. 21. The frequency response of the convex replaceable protector (single pulse, duration of $0.5 \mu \mathrm{s}$ ).

\section{Conclusions}

Low frequency broadband ultrasonic transducers were investigated using simulation and experimental methods. The square shape pulses of a half period (single pulse) and three periods were used for excitation of the broadband 
transducers. These pulses give the frequency responses with many lobes, the bandwidth of which depend on the band width of the driving pulse.

The broadband transducers may operate in the frequency range from $50 \mathrm{kHz}$ up to $350 \mathrm{kHz}$ with planar and convex replaceable protectors. The replaceable protector gives additional losses of the ultrasonic signal but protects the surface of the transducer against the wear during long term scanning.

\section{References}

1. Kažys R., Demčenko A., Mažeika L., Šliteris R. Air-coupled ultrasonic non-destructive testing of aerospace components. Insight. Vol. 49. N. 4. P. 1-5.

2. Stoessel R., Krohn N., Pfeiderer K., Busse G. Air-coupled ultrasound inspection of various materials. Ultrasonics. 2002. Vol. 40. P. $159-163$.

3. Raišutis R., Kažys R., Žukauskas E., Mažeika L., Vladišauskas A. Application $f$ ultrasonic guided waves for nondestructive testing of defective CFRP rods with multiple delaminating. NDT International. 2010. N 43. P. 614-624.

4. Kažys R., Mažeika L., Barauskas R., Raišutis R., Cicẻnas V., Demčenko A. The analysis of interaction of Lamb with defects in loaded steel plates. Ultrasonics. 2006. Vol. 44. P. ell 127-ell 130.

5. Mažeika L., Raišutis R., Maciulevičius A., Žukauskas E., Kažys R., Seniūnas G., Vladišauskas A. Comparison of several techniques of ultrasonic Lamb waves velocities measurements. Ultragarsas. 2009. Vol. 64. No. 1. P. 11-17.

6. Vladišauskas A., Šliteris R., Raišutis R., Seniūnas G., Žukauskas E. Application of ultrasonic transducers for investigation of composite materials. Ultragarsas. 2009. Vol. 64. No. 4. P. 36-43.
7. Vladišauskas A., Šliteris R., Raišutis R., Seniūnas G. Contact ultrasonic transducers for mechanical scanning systems. Ultragarsas. 2010. Vol. 65. No. 2. P. 30-35.

8. Vladišauskas A., Raišutis R., Šliteris R., Seniūnas G., Jankauskas A. Investigation of the characteristics of the frequency broadband contact transducers. Ultragarsas. 2010. Vol. 65. No. 3. P. 41-44.

A. Vladišauskas, L. Mažeika, R. Šliteris, R. Raišutis, A. Jankauskas

Impulsinès ir dažninės plačiajuosčių žemojo dažnio pjezokeitiklių charaktersitikos

Reziumè

Nagrinèjamos dažninès ir impulsinès plačiajuosčiu žemojo dažnio pjezokeitikliu charakteristikos. Sumoduliuotos dažninès žadinimo impulsų charakteristikos ir eksperimentiškai ištirtos taikant vieno ir triju teigiamuju periodu impulsus. Eksperimentuose buvo naudojamas plačiajuostis žemojo dažnio pjezokeitiklis. Gautieji dažniniu charakteristikų spektrai nuo 0 iki 1,0 $\mathrm{MHz}$ parodè, kad spektrų lapeliu plotis priklauso nuo žadinimo impulsų pločio ir kinta nuo $75 \mathrm{kHz}$ iki 400 $\mathrm{kHz}$, jei žadinama vienu periodu. Kai žadinama trimis periodais, lapeliu plotis tris kartus mažesnis negu tuo atveju, kai žadinama vienu periodu.

Išmatuotos impulsinès ir dažninès vienu ir trimis pusperiodžiais žadintu pjezokeitiklių be papildomų sluoksniu ir su plokščiais ir išgaubtais papildomais sluoksniais charakteristikos plačiame dažniu diapazone. Tam tikslui buvo naudojami du plačiajuosčiai žemojo dažnio pjezokeitikliai, kuriu vienas - siuntiklis, kitas - imtuvas. Impulsines charakteristikas žemuose dažniuose $(50 \mathrm{kHz})$ sudaro papildomi šių dažniu svyravimai.

Dažninès charakteristikos esant plokštiems sluoksniams neturi papildomu minimumu, o dažninės charakteristikos su sferiškai išgaubtu sluoksniu turi papildomų minimumų ir šie gali daryti itaką matavimo rezultatų interpretacijoms dažnių srityje.

Pateikta spaudai 20110322 